\title{
O comum do singular
}

\author{
Januário Garcia*
}

\author{
"Atenção! Sou fotógrafo, \\ não sei escrever com a caneta, \\ fotografar é arte de escrever com a luz." \\ Januário Garcia
}

Há mais de quarenta anos desenvolvo um projeto tão pessoal quanto coletivo, retratando incansavelmente negros e negras, quilombolas, pais e mães de santo, capoeiristas, foliões do Carnaval, crianças e pessoas povo, todos afro-descendentes, no Brasil, na diáspora e no continente africano. É como se eu perseguisse os "genomas culturais" da Mãe África no cotidiano, nas expressões e costumes de seus filhos. Principalmente naqueles que não vivem mais no continente materno, que a Arqueologia aponta como berço da humanidade. Ao longo dos anos, fotografo incansavelmente as múltiplas expressões culturais de matrizes africanas, bem como as manifestações políticas ligadas à negritude.

Mas para eu conseguir implementar esse trabalho percorri uma longa estrada difícil, com muitos abismos e um perigo constante de choques de frente dentro das redações de jornais, nas agências de publicidade, nas gravadoras de discos, por um simples motivo, eu sempre quis deixar claro para os os chefes de redação, para os diretores de criação das agências e para os produtores de discos, que eu tenho consciência que sou negro e combato o racismo. Essa minha postura me permitiu transitar por esses espaços com desenvoltura, respeitando e sendo respeitado, sempre procurei trabalhar como Freelancer para eu ter um espaço aberto para fazer críticas, porque se você é um empregado da casa, não poderia fazer. Trabalhei nas redações do O Globo, Jornal do Brasil, O Dia, A Notícia; fui convidado por Zuenir Ventura para ser colaborador da Veja. Trabalhei na Editora Block, nas revistas Manchete, Fatos e Fotos. Trabalhei com as grande agências de publicidade do Rio de Janeiro, como a MPM, Thompson, Contemporânea, DM 9, Professa e outras. Sou autor de 4 capas de discos de Antonio Carlos Jobim, 2 de Fagner, 2 de Chico Buarque, 4 de Leci Brandão, 2 de Raul Seixas, 2 de Belchior, 2 de Caetano, 2 de Fafá de Belém, Nei Lopes e Wilson Moreira, Edu Lobo, Maria Betânia e outros artistas. Paralelo ao meu

\footnotetext{
*Formado em fotografia pela International Camaraman Association. Possui atuação profissional nas áreas da publicidade, da música, do jornalismo e do cinema. Documenta a trajetória do negro no Brasil e na Diáspora Africana. E-mail:janufotos@yahoo.com.
} 


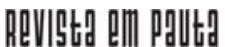

\} O COMUM DO SINGULAR - GARCIA, J. \}

DOI: 10.12957/REP.2020.52019

trabalho profissional de subsistência, sempre fiz o meu trabalho pessoal que é a construção da memória negra.

Durante todo esse tempo, venho mantendo esse trabalho que hoje chamo de Documenta Fotográfica Brasileira de Matrizes Africanas. O objetivo principal é a documentação fotográfica contemporânea de negros que estão em diferentes espaços nas cidades e nos campos. Estou registrando a mobilidade, presença e afirmação do negro como parte importante do processo civilizatório. É um conjunto de imagens que transmite um novo olhar, uma nova postura diante de uma sociedade que desconhece a importância civilizatória das culturas africanas para a humanidade.

A proposta deste trabalho é ser uma síntese desse processo, e também o principal trabalho de minha vida, pois ele é o alicerce da função política e social que exerço enquanto fotógrafo. Não tem nada de difícil entendimento, são registros simples que costumo chamar de $O$ comum do singular, que encerra uma lógica aparentemente contraditória, e nos convida a refletir sobre a questão da alteridade, da diferença (o singular). E ao mesmo tempo nos convida a refletir sobre as bases humanas e culturais que temos em comum, aquelas que podem ser compartilhadas, a despeito de quaisquer diferenças.

A história das civilizações, transcorrida sobre a plataforma da dominação de um povo sobre outro, é muito elucidativa no que diz respeito às estratégias de criação de imagens distorcidas da realidade, para colocálas a serviço das classes dominantes.

Se meu olhar sobre o outro, o diferente é construído com base numa relação de colonização opressiva, a estratégia é apresentá-lo como estranho, diferente demais, portanto, como um ser perigoso que precisa ser mantido sob controle. Para melhor justificar tais relações de dominação e evitar os questionamentos contra o processo de sujeição de seres humanos por outros seres humanos, mais estratégico ainda é apresentar esse outro como inferior, como irracional, próximo da esfera animal. Por isso os povos indígenas aqui no Brasil não tinham alma e os negros tomados como escravos na África eram comparados a primatas. A construção desses tipos de imagens distorcidas era necessária ao processo de dominação, tanto para anestesiar consciências, como para manter ativo o processo de exploração econômica das colônias. Não é nada diferente dos dias atuais, quando se constrói pela mídia nacional a imagem dos negros nas favelas como a de um bando de marginais, portanto, irracionais, portanto, perigosos, sabendo que não representam nem $2 \%$ dos moradores locais, ordeiros e trabalhadores oprimidos de cima para baixo pelos bandidos e de baixo para cima pelas polícias.

Assim, simultaneamente eu questiono a singularidade estabelecida como fator de opressão ou de inferiorização do outro. Insere-se como igual, como comum entre os oprimidos e nos instiga a fazer da luta antirracista a nossa luta, um esforço compartilhado pela efetiva igualdade racial no Brasil. 


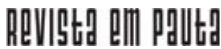

\} O COMUM DO SINGULAR - GARCIA, J. \}

DOI: $10.12957 / R E P .2020 .52019$

O meu trabalho procura mostrar a cada brasileiro o que enfrentamos aqui no nosso cotidiano, mas não me limito as nossas fronteiras, vou além delas: já expus em países da Europa, do Oriente Médio, da América Central, da América do Sul, da América do Norte e da África. Em 2004, por exemplo, consagrado pela ONU/UNESCO como o Ano Internacional de luta contra a Escravidão e sua Abolição, o meu trabalho foi escolhido como referência e foi apresentado na sede da ONU em Nova York, na abertura da Assembléia Geral Anual. A exposição foi montada no Saguão do Secretariado, local onde são recebidos os Chefes de Estado e Chefes de Governos presentes na Assembléia. Indo um pouco mais além, temos o Diásporas Africanas na América do Sul - Uma Ponte Sobre o Atlântico, que é o título de um livro que fiz em parceria com o antropólogo Julio Cesar de Tavares, também militante negro. Esse livro mostra as comunidades negras além do Brasil: Argentina, Colombia, Perú, Venezuela, Suriname e Uruguai.

Consultando a história da fotografia brasileira, recuamos até o século XIX. Veremos uma fotografia e uma estética apropriada pela ciência, transformada em aparente documento histórico e etnográfico, nas mãos de pesquisadores europeus. Tais imagens, embora revestidas pelo manto da ciência, jamais foram neutras ou imparciais. Pelo contrário, revelam todo um posicionamento sociocultural de seus autores, a serviço (consciente ou inconsciente) das estratégias de colonização.

Muito comuns são imagens de negros e indígenas, como as de Emil Goeldi, fotografados de frente e de perfil, tendo ao meio uma vara de medidas antropométricas. Tal procedimento foi realizado em diversos continentes. Se por um lado a vara de medidas indica "objetividade científica", como negar que, dessa mesma forma, desde meados do século passado, eram identificados os criminosos ${ }^{1}$. Além disso, tais fotografias procuravam marcar patologias, assim como as diferenças nas configurações do crânio ou dos traços faciais (em relação ao padrão europeu), numa época em que estavam em voga os preceitos da fisiognomia de Lavater e a frenologia de Gall, que pressupunham tendência ao crime pelos indivíduos que possuíssem determinados aspectos na sua constituição física.

Outro fator de discriminação, nas fotos dessa época: os retratos dos brancos dominantes eram identificados por seu nome e sobrenome. Já os índios e escravos eram identificados por suas tribos ou grupos étnicos. Massificados e etiquetados, tinham suas identidades como indivíduos anuladas.

Também no século passado são inúmeras as fotografias de índios e negros apresentados como seres exóticos, diferentes, vendidas em forma de cartões postais. No caso dos índios, a estratégia era ocultar suas inúmeras

\footnotetext{
1 Para mais detalhes, ler o artigo "Ciência e Exotismo: os índios na fotografia brasileira do século XIX", de Susana M. Dobal, in Cadernos de Antropologia e Imagem, N. ${ }^{\circ} 12$ - A Imagem do Índio no Brasil, UERJ, NAI - Núcleo de Antropologia e Imagem, Rio de Janeiro, 2001.
} 


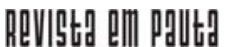

\} O COMUM DO SINGULAR - GARCIA, J. \}

DOI: $10.12957 /$ REP.2020.52019

rebeliões contra os colonizadores e apresentá-los como seres tornados dóceis, ou, nas palavras de Susana M. Dobal², como "criaturas já pacificadas, prontas para o consumo turístico e científico". Marc Ferrez foi um dos fotógrafos que registrou índios e negros buscando evocar sua beleza, agregando às imagens o valor do exotismo, para consumo turístico (ele vendia as imagens em forma de cartões postais)! Como bem afirmou Suzana M. Dobal ${ }^{3}$ :

Cientistas e pesquisadores europeus percorriam colônias diversas no Século XIX com o nobre propósito de preservar o que estava prestes a ser dizimado, fosse uma raça, os objetos de uma cultura, mitos ou línguas. Sua tarefa era apoiada pelos governos de países europeus, pois, para além das causas humanitárias, havia obviamente o interesse econômico em vencer obstáculos e abrir caminho para a exploração comercial das colônias - prova disso, viajantes e exploradores tinham apoio financeiro tanto de instituições científicas como de instituições comerciais. A participação da fotografia nesse panorama foi fornecer um corpo de imagens coerente com toda a engrenagem: imagens que podiam, portanto, transitar tanto no meio científico como no estúdio comercial dos fotógrafos, fazendo assim a ligação entre a ciência e o contexto cultural local, entre a régua na foto da índia botocuda e a moldura ornamentada em volta dela. A câmera fotográfica permitia a todos uma confortável atribuição de papéis: de um lado o cientista, o fotógrafo, o turista que comprava imagens; de outro, a índia ou a escrava devidamente caracterizadas como tipos.

A imagem do negro sempre foi mostrada como uma representação arbitrária e excludente. Na visão judaico-cristã, por exemplo, o negro era associado à cor das trevas e do mal. Portanto, o negro não seria digno das bênçãos de Deus. É a partir dessa lógica que vamos encontrar os fundamentos da escravização, do preconceito e do racismo contra o negro. (DOBAL, 2001)

Por que motivo os negros, em grande maioria, moram nos cortiços? A resposta, asseguro-lhe, é muito fácil: a pouca valia que imprimem aos seus trabalhos; a pouca ou nenhuma cultura e a acentuada dolência dos seus passos; a inércia e a falta de vontade e iniciativa para uma reação na trilha do progresso, são as causas principais que obrigam os negros às misérias do cortiço. (FOLHA DA MANHÃ, 1930)

O trecho transcrito logo acima faz parte do editorial "Ironia de um congresso", do jornal Folha da Manhã (atual Folha de S.Paulo), publicado num domingo, 12 de janeiro de 1930. Trata-se de uma crítica ao movimento da Mocidade Negra, uma das manifestações características da época. 


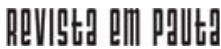

\} O COMUM DO SINGULAR - GARCIA, J. \}

DOI: $10.12957 /$ REP.2020.52019

A imagem negativa do negro é histórica e cultural. Após a abolição, nós negros fomos jogados para fora do mercado de trabalho. O projeto cultural da construção da república em 1889 nos colocou de ex-escravos para negros desempregados, ociosos, inferiores. Não nos reconheceu como o povo brasileiro descendentes de africanos escravizados no Brasil, que é a nossa real condição.

Pesquisas acadêmicas dedicadas ao estudo do relacionamento entre o negro e a mídia, temática desenvolvida desde o final da década de 1960, apontam que os veículos de comunicação no Brasil são pródigos em perpetuar um registro embranquecido da sociedade e uma imagem subalternizada do negro, apresentando-o sempre como trabalhador desqualificado, delinquente, malandro, promíscuo, ou ainda, em sua clássica posição de escravo. A mídia estabelece um senso de nacionalidade eurocêntrico que valoriza - nos mesmos moldes da literatura oitocentista - o biótipo branco em detrimento ao negro. Os padrões positivos de representação social (beleza, sucesso, poder) são reservados à parcela branca da população, sendo relegado aos negros os papéis negativos, subalternos e de segundo plano.

Exceções únicas devem ser feitas aos cenários esportivo e musical. Nesses espaços a imagem do negro como atleta ou como artista (cantor, músico, dançarino etc) ganha projeção e valor. De certa forma, parecem ser estes os únicos meios legítimos para a ascensão do negro em nossa estrutura social.

A Estética Negra no universo das mídias é mostrada embranquecida, a publicidade assume relevância que extrapola sua função primeira de estímulo e incentivo ao consumo. Além de ser o esteio sobre o qual se desenvolve toda a indústria cultural, a publicidade é o mais eficiente vetor de discursos e mensagens simbólicas. Associando o produto oferecido a comportamentos e características socialmente desejáveis, a publicidade vende mais do que produtos, vende estilos de vida. Nessa linha, o consumidor de cigarros Marlboro fuma a masculinidade e o vigor do cowboy, enquanto o consumidor de Gatorade - mesmo aquele que não pratica esportes bebe saúde e vitalidade.

Como mostra Judith Williamson (1978), a propaganda 'interpela' os indivíduos e convida-os a identificar-se com produtos, imagens e comportamentos. Apresenta uma imagem utópica de novidade, sedução, sucesso e prestígio mediante a compra de certos bens. (...) Por conseguinte, os indivíduos aprendem a identificar-se com valores, modelos e comportamentos sociais através da propaganda. (KELLNER, p.322, 2001).

Assim como as demais formas de discurso social (entenda-se textos jornalísticos programas de TV, livros didáticos etc.) a publicidade dará eco aos valores da sociedade que a produziu. Como no Brasil os valores são 


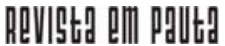

\} O COMUM DO SINGULAR - GARCIA, J. \}

DOI: $10.12957 /$ REP.2020.52019

pautados dentro de uma lógica eurocêntrica que deprecia o que não é espelho, nossos anúncios tendem a reproduzir e legitimar as desigualdades raciais.

Autores que nos últimos anos dedicaram estudos à análise da imagem do negro na publicidade - Solange Martins Couceiro de Lima (2006), Jacques d’Adesky (2001) e Maria Cristina Martins (2000), citando alguns dos mais recentes - são pródigos em afirmar que a publicidade quando não torna o negro "invisível", apresenta-o, na maioria das vezes, de maneira estereotipada.

As formas mais comuns de representação do negro nesse segmento podem ser relacionadas a dois estereótipos básicos: o trabalhador braçal, figura próxima ao ex-escravo, no qual estão inseridos frentistas, carregadores e empregadas domésticas; o artista, ou seja, o negro divertido e performático, a exemplo do personagem Sebastian (C\&A).

Foi Pierre Verger um fotógrafo francês que, viajando pelo mundo, percebeu as diferenças e suplantou esse olhar eurocêntrico. Verger redescobre o negro fora dos padrões do imaginário europeu e consegue nos revelar sua essência humana até então desconhecida ou ignorada. O negro renasce como um ser provido de uma forte cultura, capaz de suplantar todas as adversidades da escravidão, conservando seus ritos, linguagem corporal, indumentárias e modos de ser, agir e pensar. Embora retirados da África, essa África permanece dentro de cada um. O conjunto da obra fotográfica de Pierre Verger é um passo inicial para que possamos entender e compreender como os fragmentos dessa cultura foram sendo reagrupados na diáspora africana.

Esse reagrupar de fragmentos nos levou a um novo patamar de onde passamos a contrariar aquilo que estava estabelecido para nós como comportamento. Criamos novos espaços administrados por nós mesmos, o belo que sempre nos foi mostrado, já não fazia parte da nossa cartilha, procuramos nos produzir com elementos das indumentárias da nossa ancestralidade, passamos a valorizar o nosso gestual, literalmente tomamos a palavra em nossas mãos e um novo discurso surgiu, não nos deixando nenhuma dúvida sobre nossos objetivos na transformação social da luta antirracista no Brasil.

O meu trabalho tenta ser a continuação contemporânea do processo de valorização das culturas de matrizes africanas. Uma continuação das mais pertinentes, pois sou negro e, na medida em que passo para trás das câmeras, assumindo o papel de gerador consciente das imagens, inauguro um novo olhar, que é o comum do singular, o olhar de um igual entre aqueles que são considerados diferentes.

Com a fotografia cada vez mais ganhando espaço e se constituindo em ferramenta de documentação e registro, essa representação negra sofre uma transformação radical. O próprio negro sai da frente da câmera e passa a ser o produtor das imagens. Com seu olhar passa a criar imagens de 


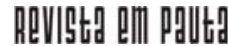

\} O COMUM DO SINGULAR - GARCIA, J. \}

DOI: $10.12957 /$ REP.2020.52019

si mesmo. É o negro ser, visto em si mesmo e por si mesmo. É reconstruir séculos de história de si mesmo, é buscar resgatar a autoestima a despeito de séculos de humilhações sofridas e perpetuadas através da pobreza, do abandono social e do tratamento excludente. É o negro voltando o olhar para si mesmo, buscando no fundo da alma um lampejo de orgulho e alegria que se transformam em essência da beleza de sua humanidade, desde dentro para desde fora.

DOI: $10.12957 /$ rep.2020.52019

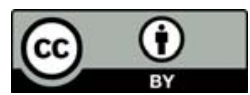

A Revista Em Pauta: Teoria Social e Realidade Contemporânea está licenciada com uma Licença Creative Commons Atribuição 4.0 Internacional. 


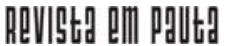

\} O COMUM DO SINGULAR - GARCIA, J.

DOI: $10.12957 /$ REP.2020.52019

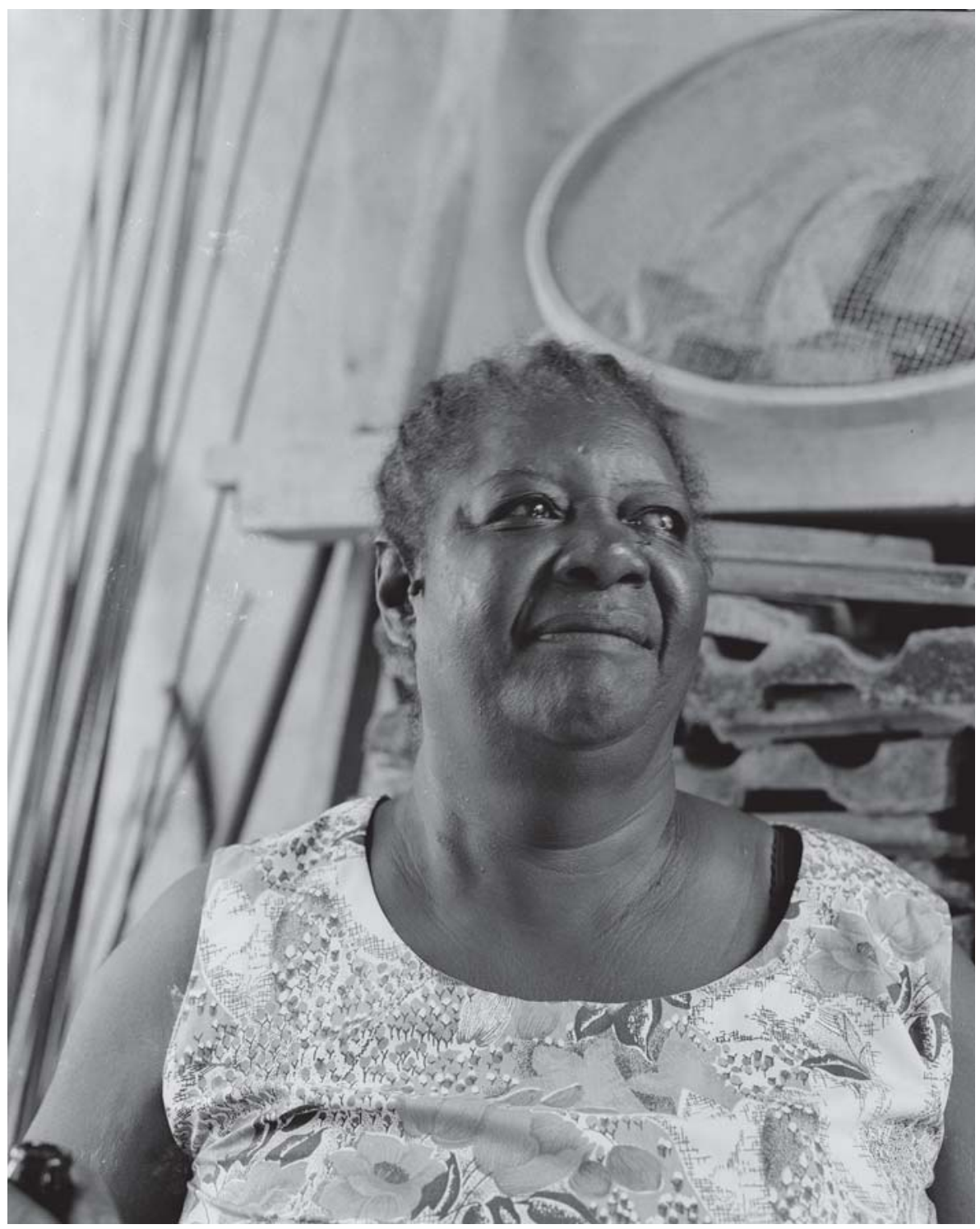

Dona Ana Bororó, liderança do morro do Salgueiro 


\section{ReVIIStg an PaUtA}

\} O COMUM DO SINGULAR - GARCIA, J. \}

DOI: 10.12957/REP.2020.52019

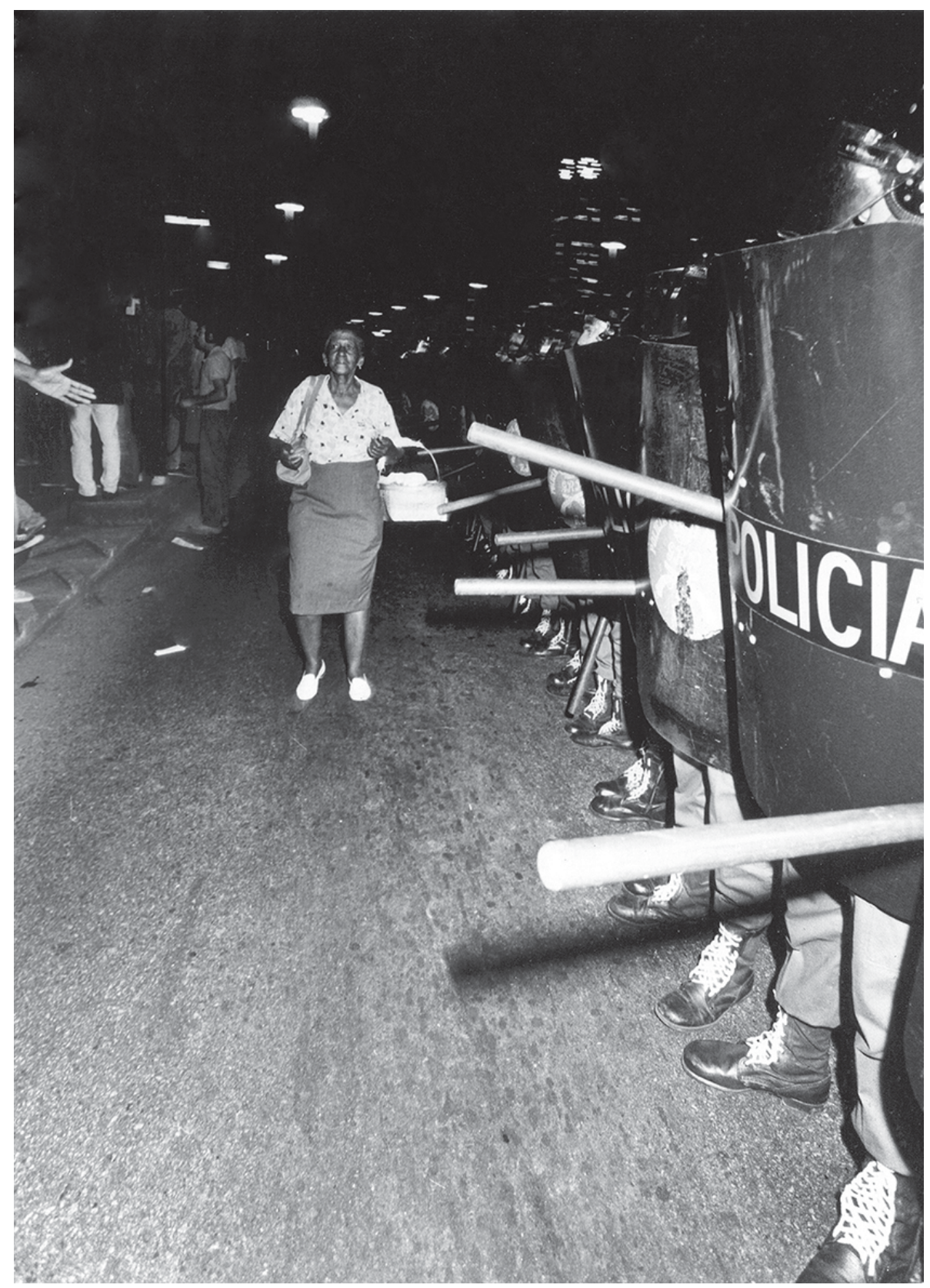

Marcha Farsa da Abolição - maio de 1988 


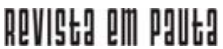

\} O COMUM DO SINGULAR - GARCIA, J. \}

DOI: 10.12957/REP.2020.52019

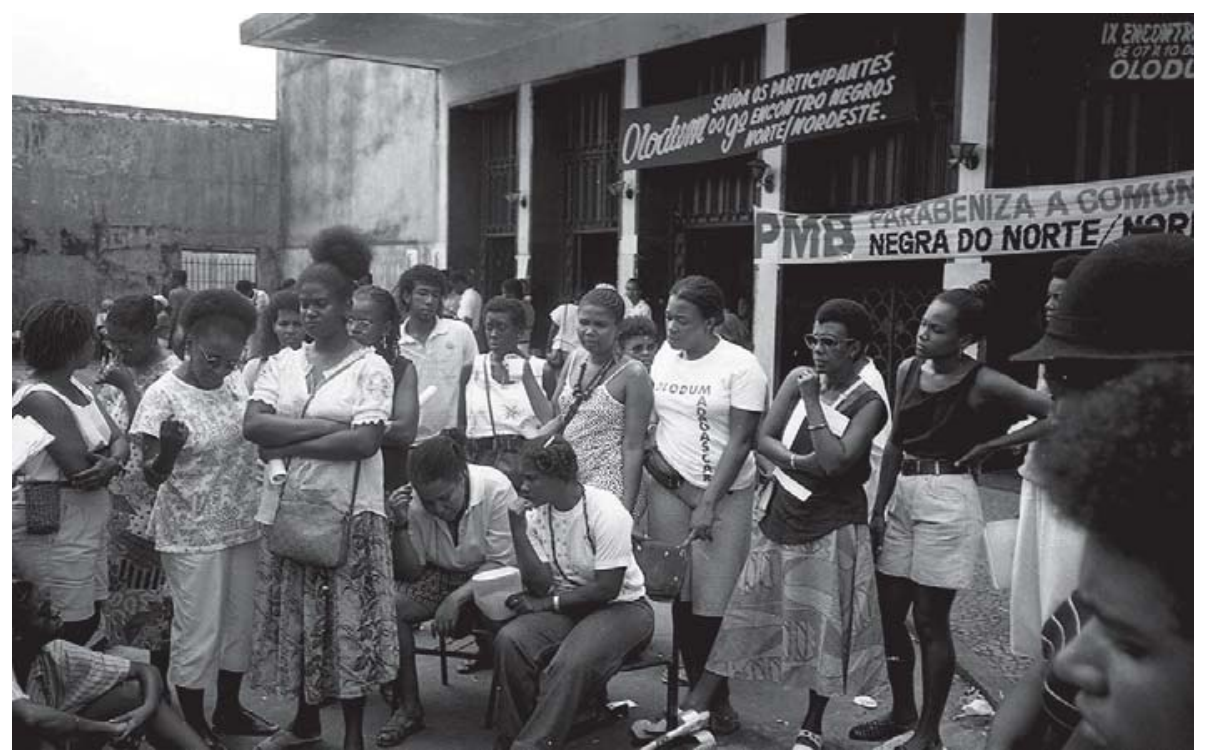

IX Encontro Norte Nordeste - Salvador, 1990 


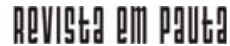

\} O COMUM DO SINGULAR - GARCIA, J. \}

DOI: $10.12957 / R E P .2020 .52019$

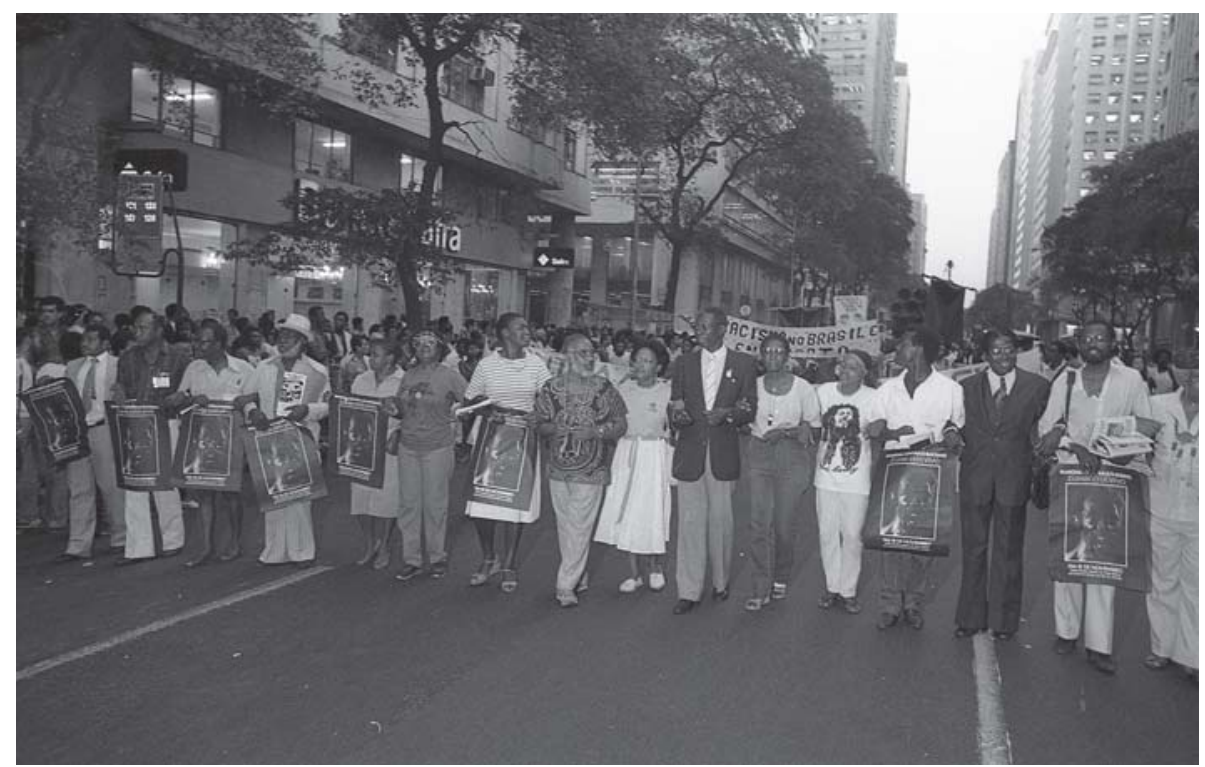

Marcha 20 de Novembro de 1985 - Rio 


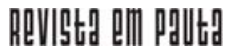

\} O COMUM DO SINGULAR - GARCIA, J. \}

DOI: $10.12957 /$ REP.2020.52019

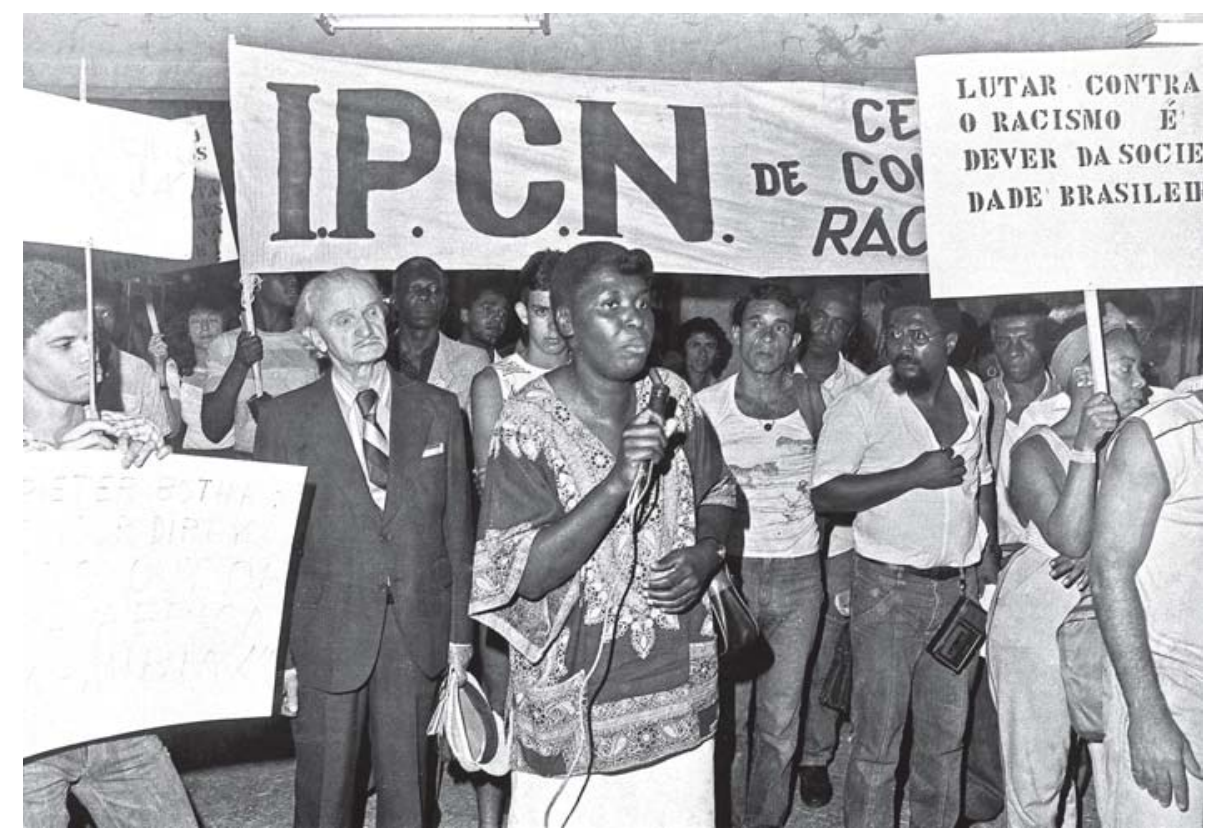

Benedita da Silva - Ato Público do MN 


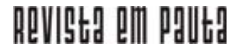

\} O COMUM DO SINGULAR - GARCIA, J. \}

DOI: $10.12957 /$ REP.2020.52019

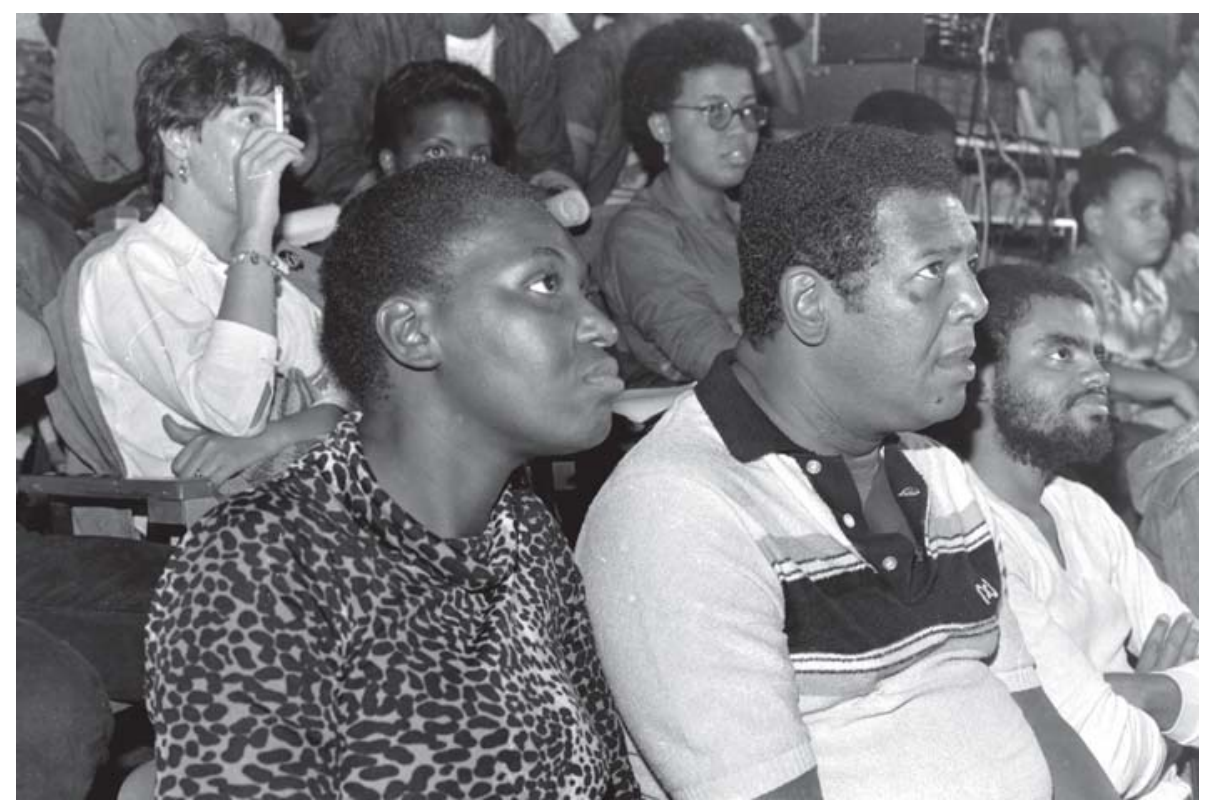

Benedita da Bilva e Bola 


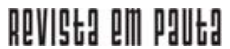

\} O COMUM DO SINGULAR - GARCIA, J. \}

DOI: $10.12957 /$ REP.2020.52019

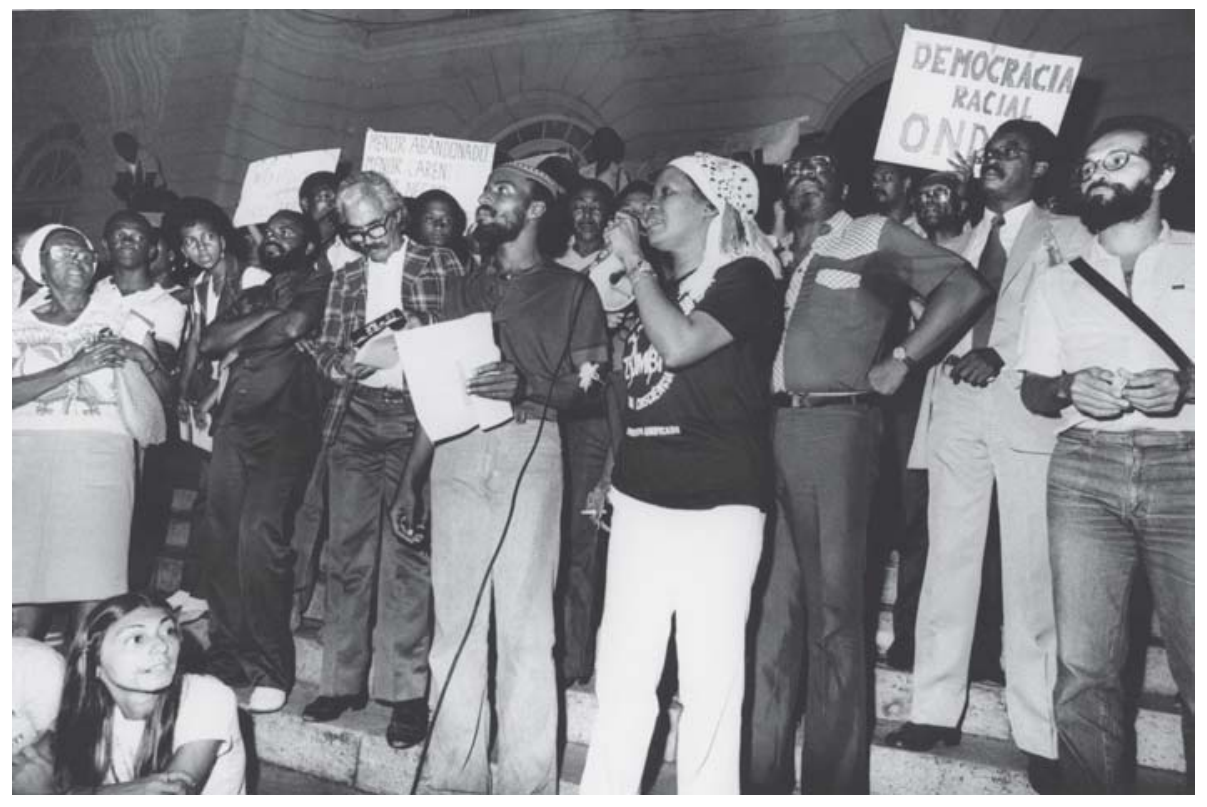

Lélia Gonzalez - Ato Público do MN 


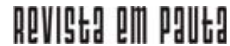

\} O COMUM DO SINGULAR - GARCIA, J. \}

DOI: $10.12957 / R E P .2020 .52019$

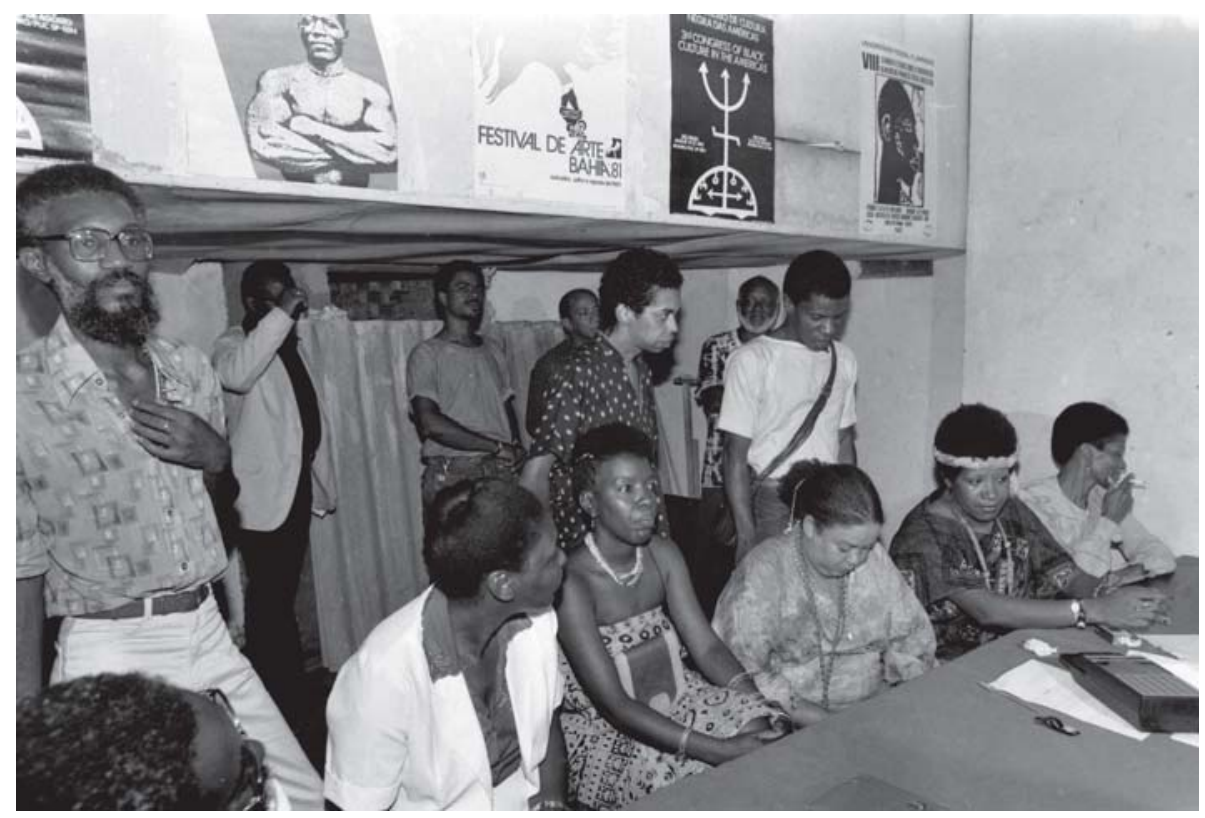

Posse da diretoria do IPCN (Instituto de Pesquisas das Culturas Negras), 1982 


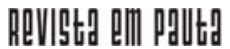

\} O COMUM DO SINGULAR - GARCIA, J. \}

DOI: $10.12957 /$ REP.2020.52019

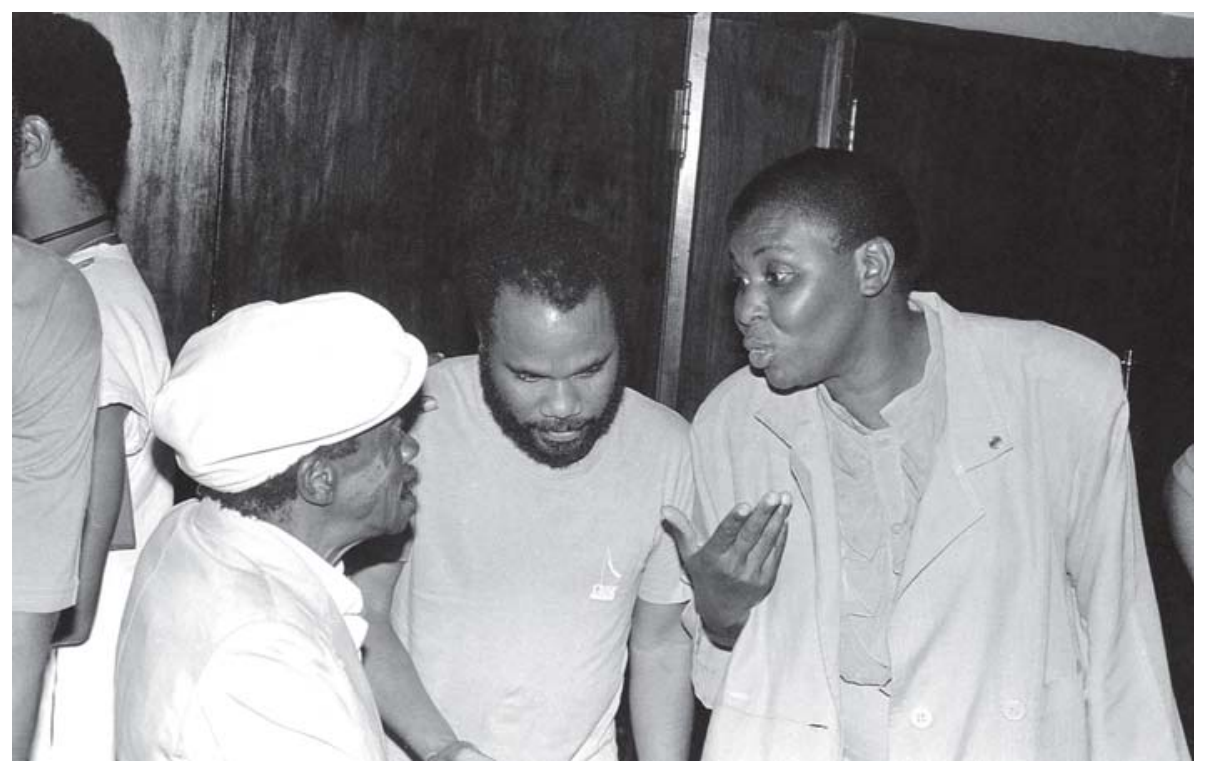

Benedita da Silva, Grande Otelo, Ivanir dos Santos 


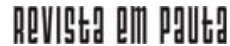

\} O COMUM DO SINGULAR - GARCIA, J. \}

DOI: $10.12957 / R E P .2020 .52019$

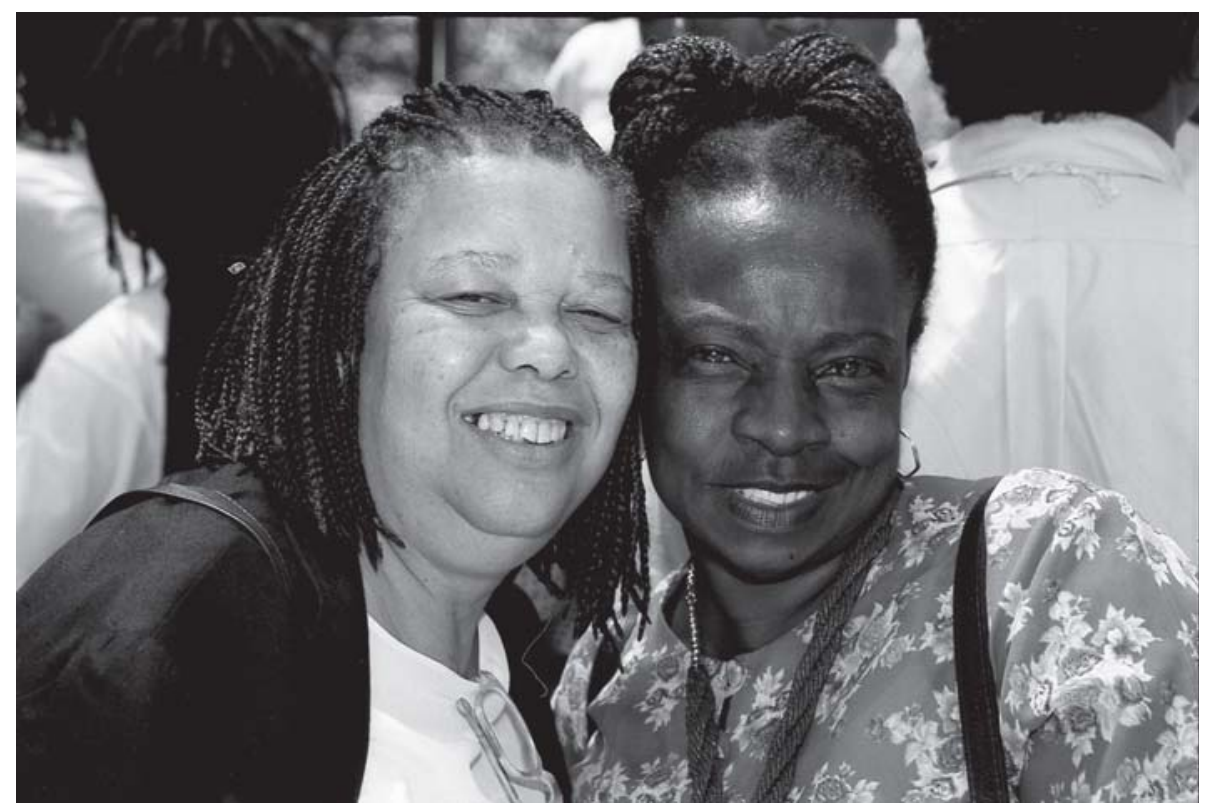

II ENEN Rio 1983 - Abgail Paschoa e Creuzelly Ferreira 


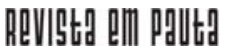

\} O COMUM DO SINGULAR - GARCIA, J. \}

DOI: $10.12957 /$ REP.2020.52019

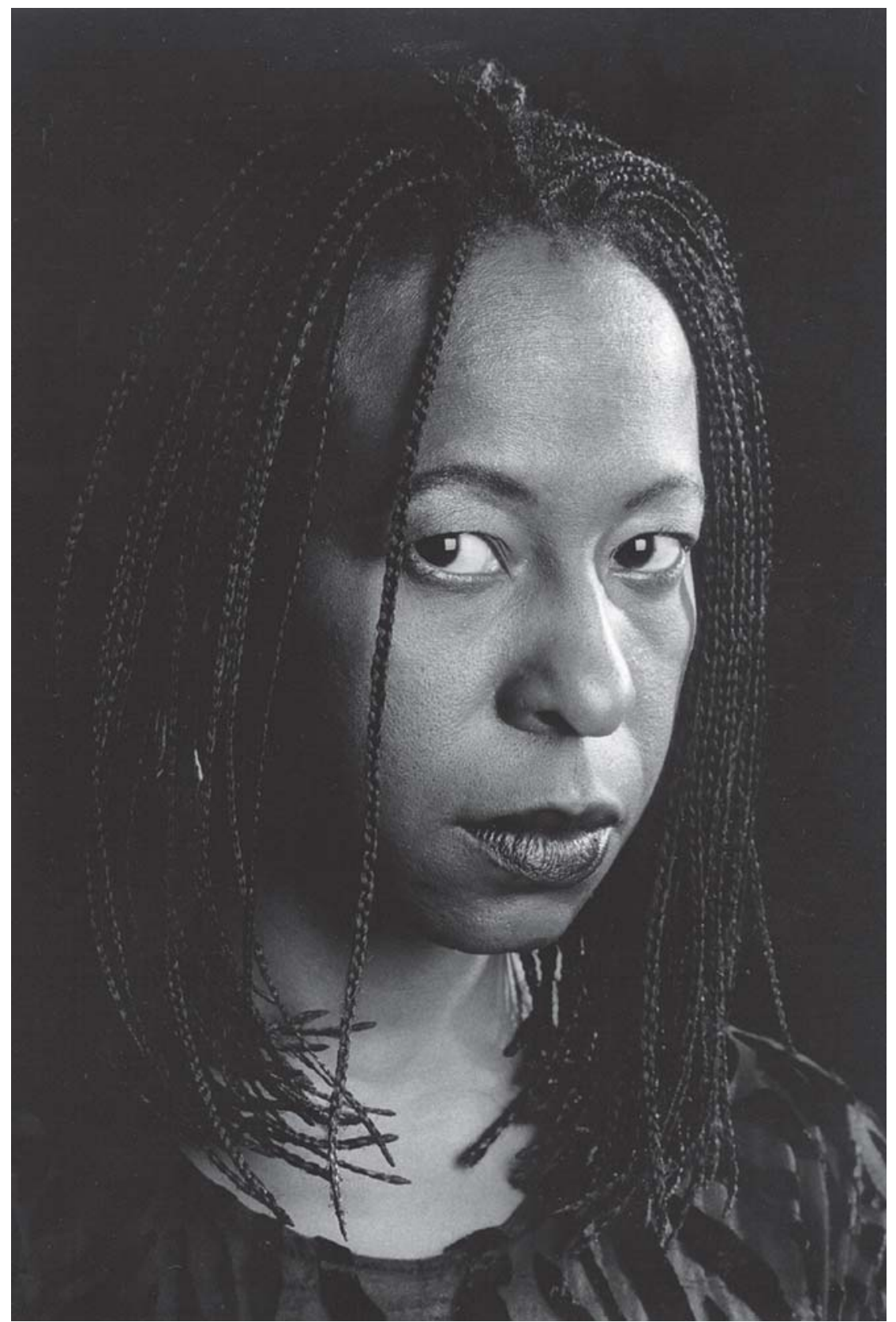

Aduni Benton, diretora de teatro e ativista do MN 


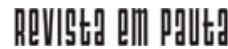

\} O COMUM DO SINGULAR - GARCIA, J. \}

DOI: $10.12957 /$ REP.2020.52019

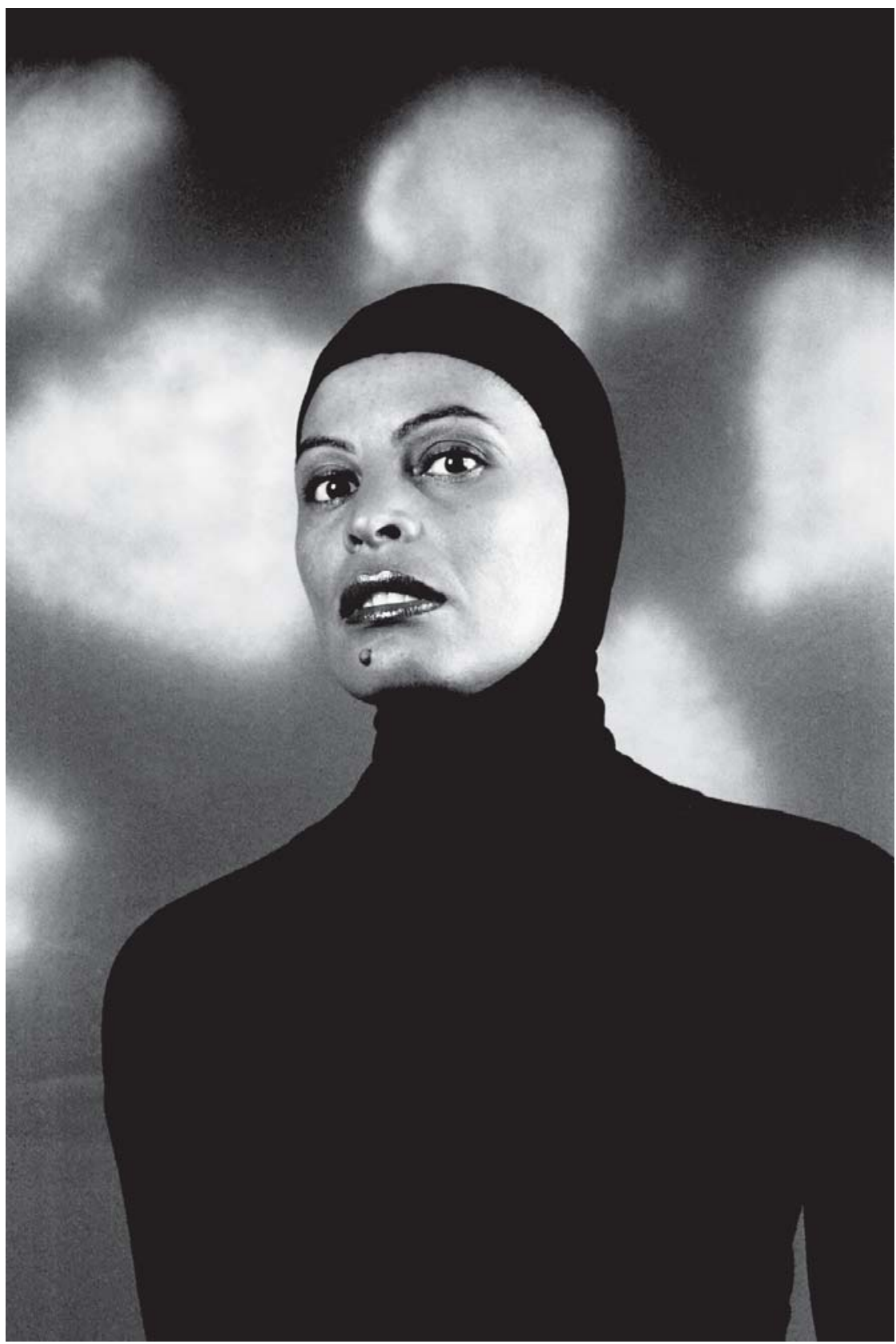

Veluma, modelo e ativista negra 


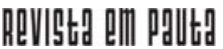

\} O COMUM DO SINGULAR - GARCIA, J.

DOI: $10.12957 /$ REP.2020.52019

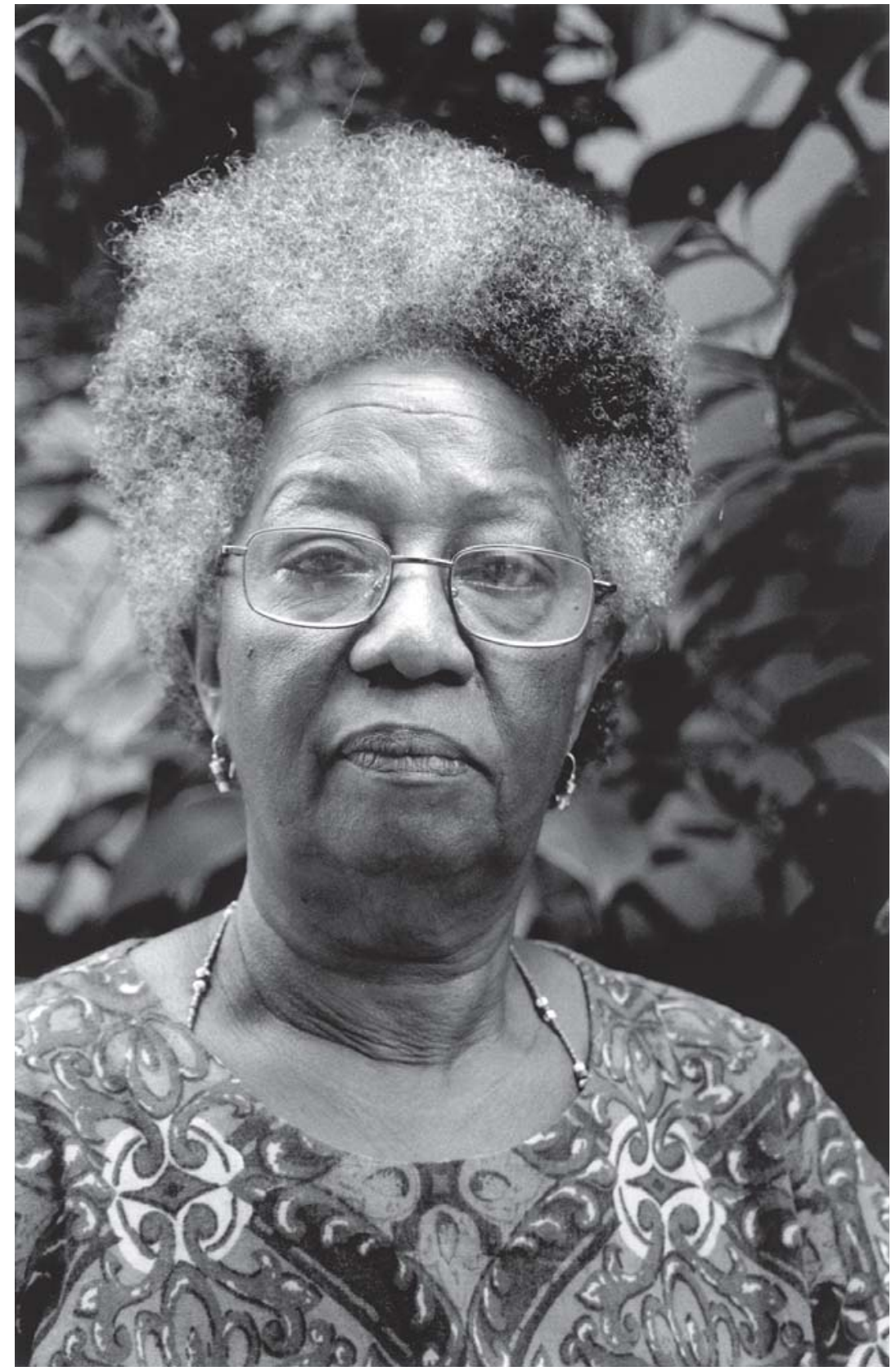

Makota Valdina 


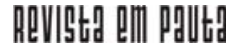

\} O COMUM DO SINGULAR - GARCIA, J. \}

DOI: 10.12957/REP.2020.52019

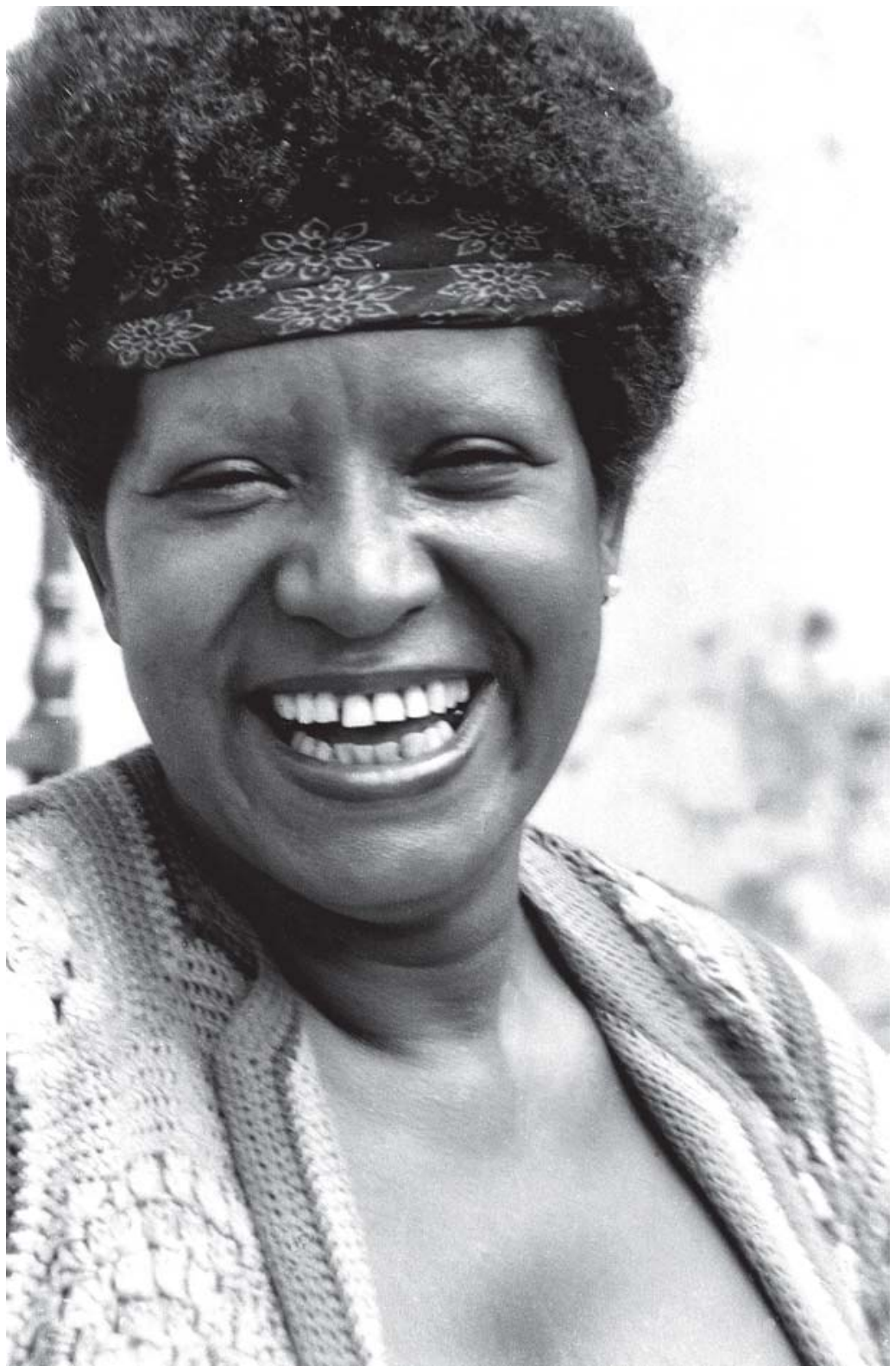

Lélia Gonzalez 


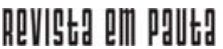

\} O COMUM DO SINGULAR - GARCIA, J. \}

DOI: $10.12957 /$ REP.2020.52019

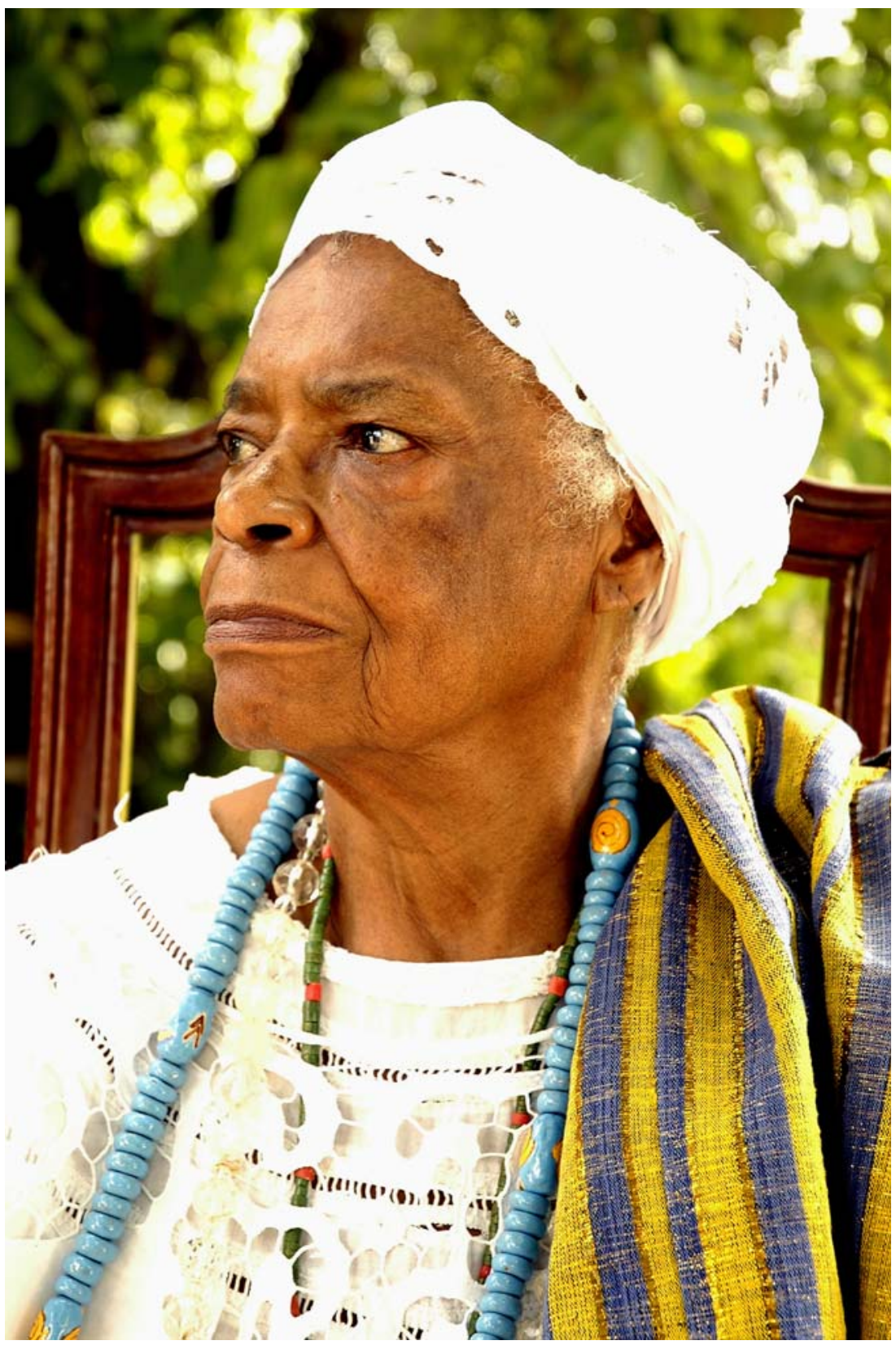

Mãe Stella de Oxossi 


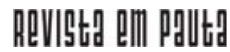

\} O COMUM DO SINGULAR - GARCIA, J.\}

DOI: $10.12957 /$ REP.2020.52019

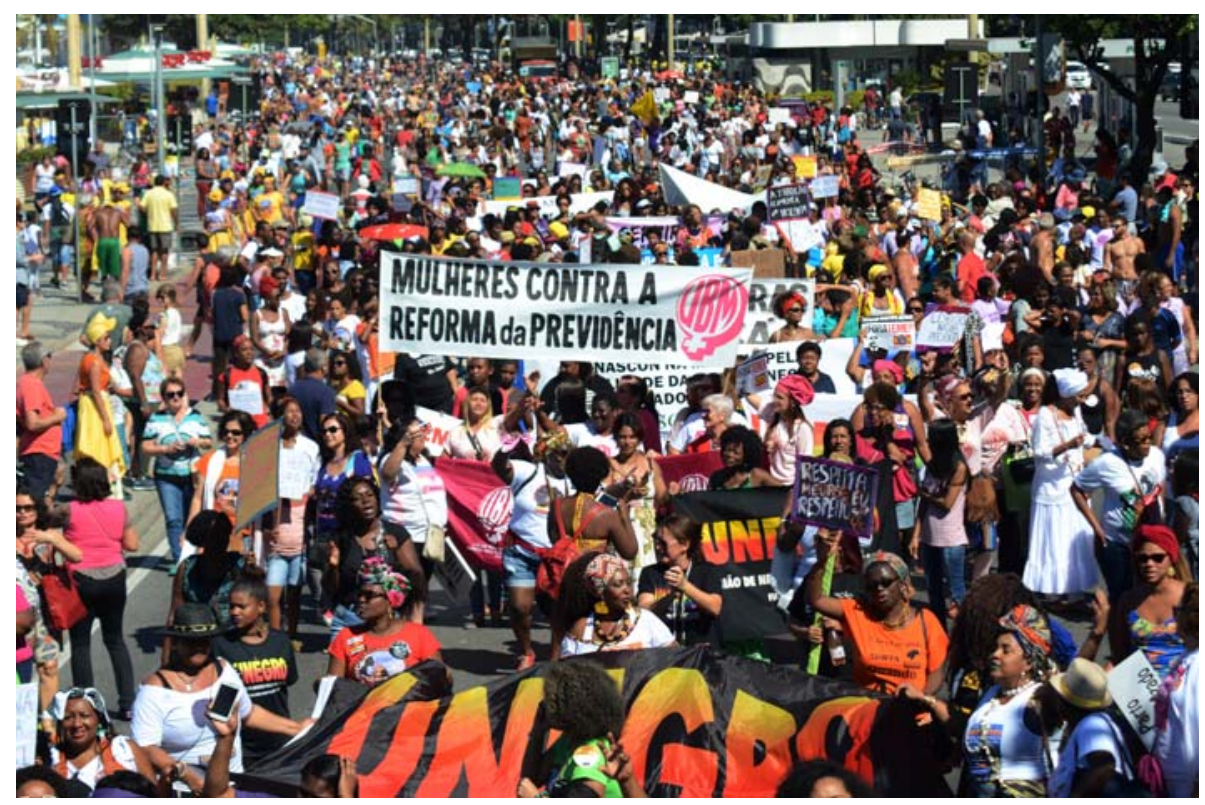

Marcha das Mulheres Negras, 2018 


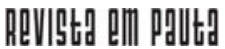

\} O COMUM DO SINGULAR - GARCIA, J. \}

DOI: 10.12957/REP.2020.52019

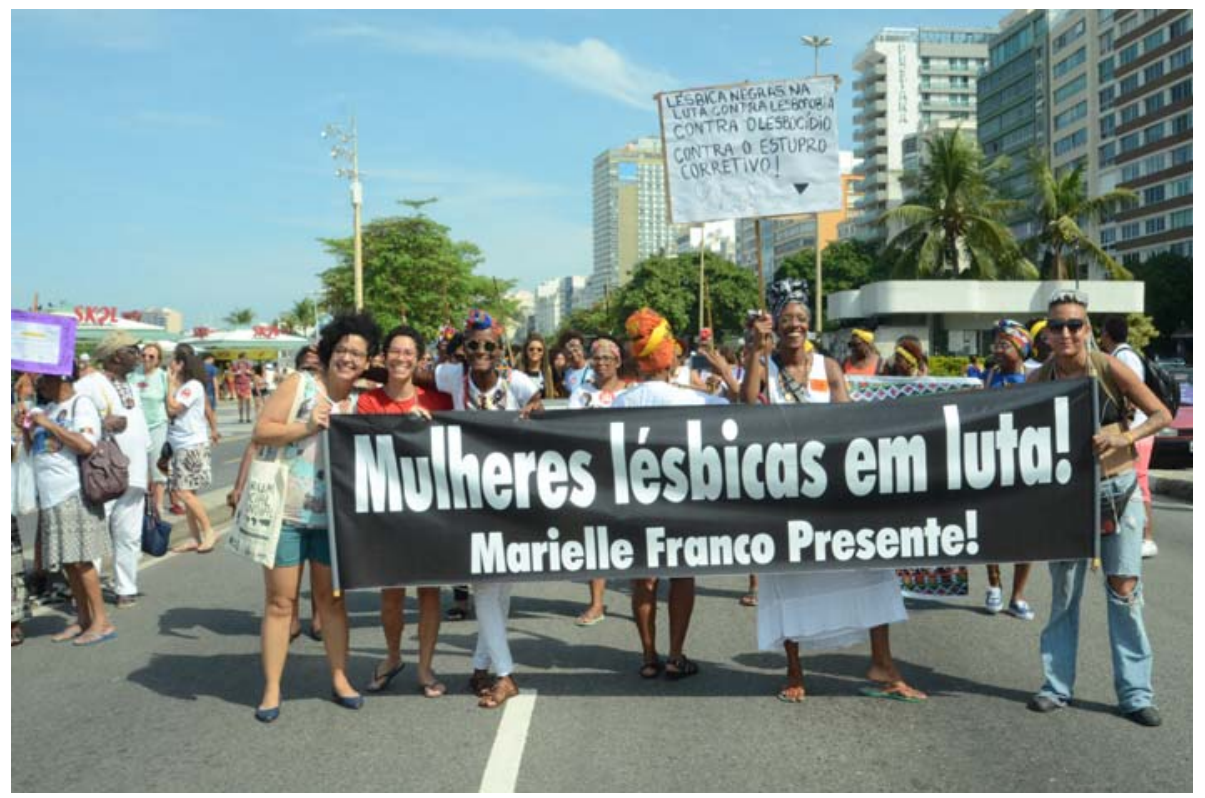

Marcha das Mulheres Negras, 2019 


\section{ReVIIStg an PaUtA}

\} O COMUM DO SINGULAR - GARCIA, J. \}

DOI: $10.12957 / R E P .2020 .52019$

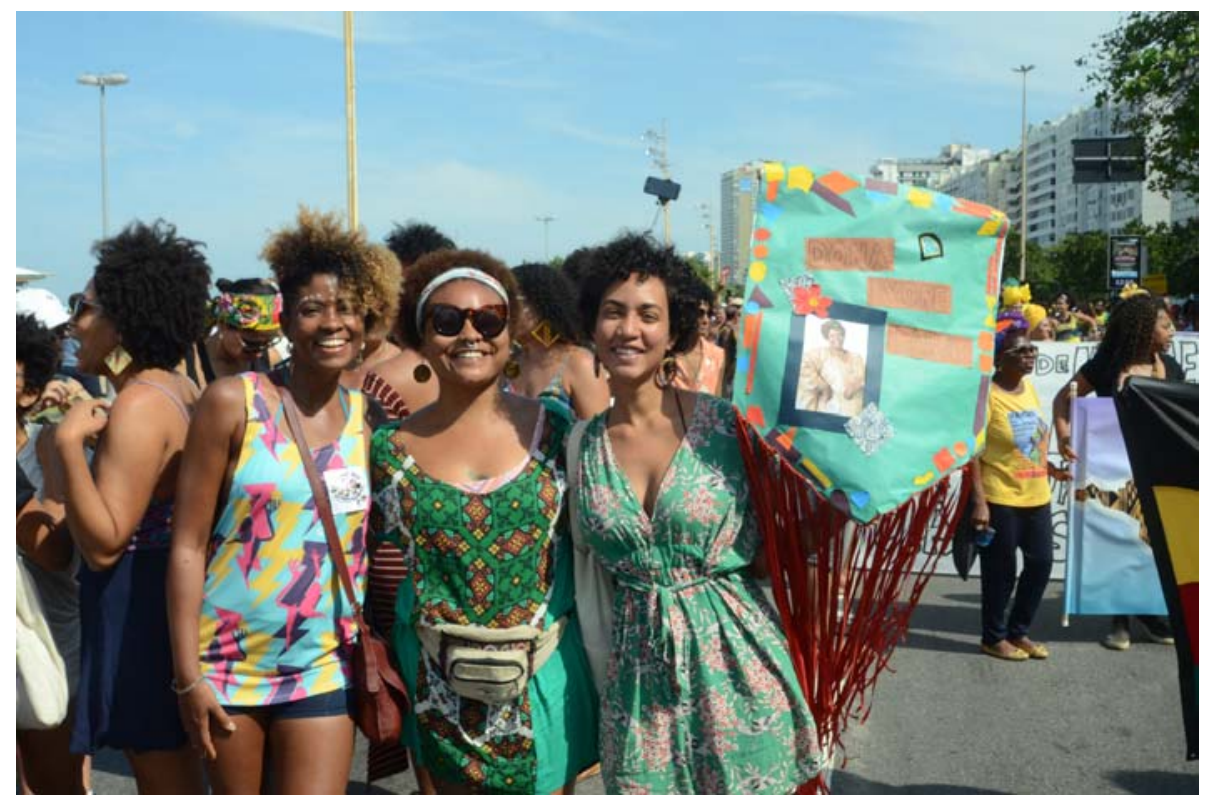

Marcha das Mulheres Negras, 2019 


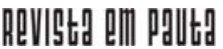

\} O COMUM DO SINGULAR - GARCIA, J.

DOI: $10.12957 /$ REP.2020.52019

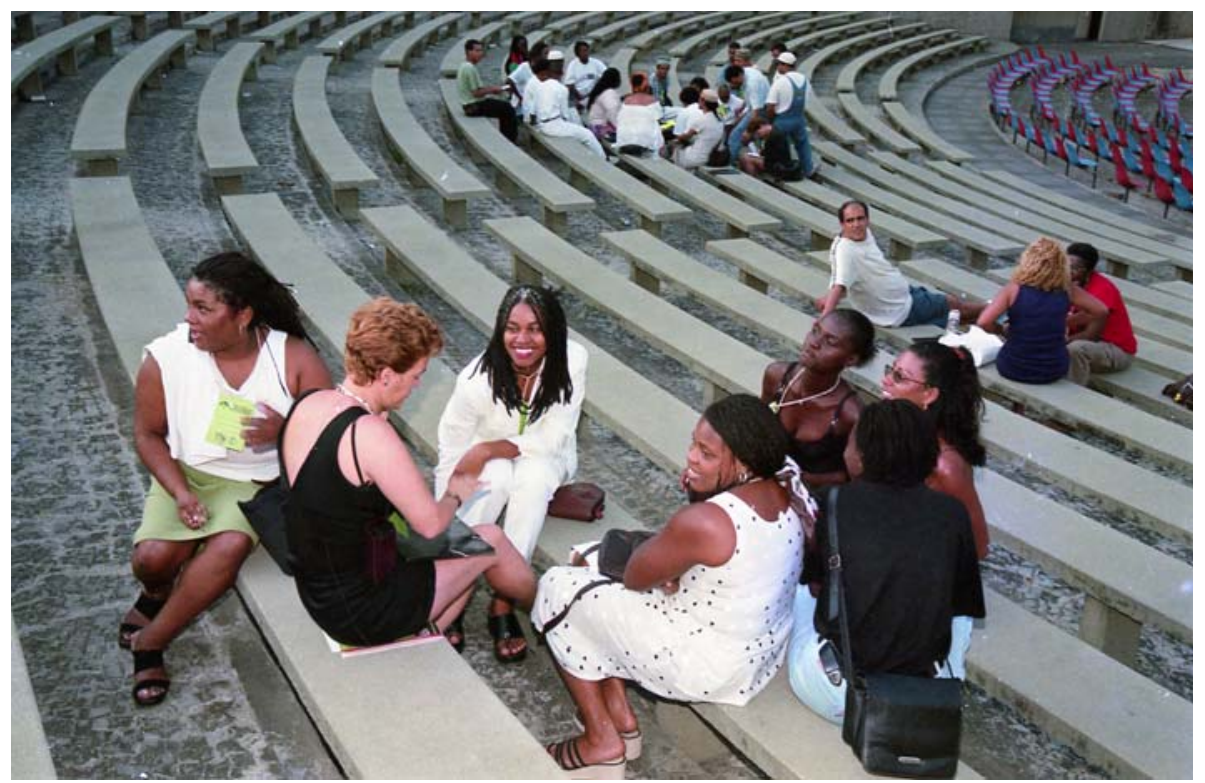

II ENEN Rio, 1983 


\section{ReVIIStg an PaUtA}

\} O COMUM DO SINGULAR - GARCIA, J. \}

DOI: $10.12957 / R E P .2020 .52019$

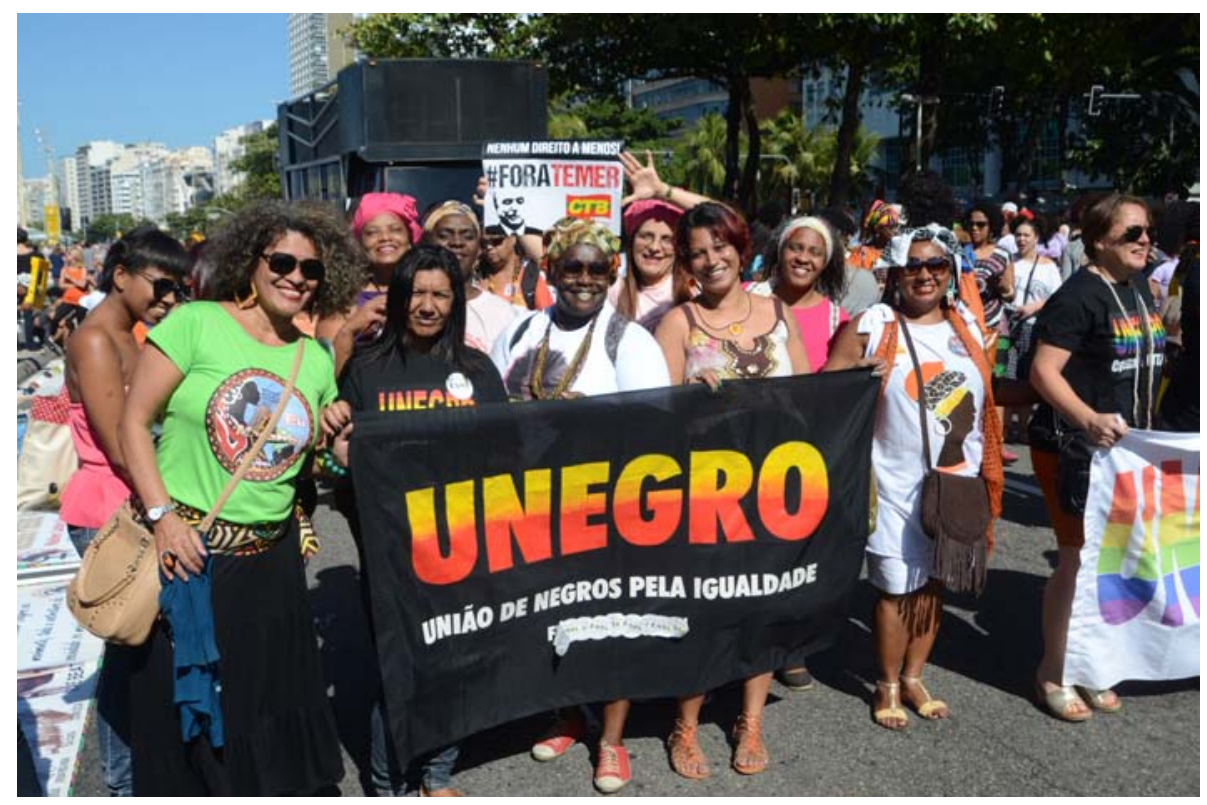

Marcha das Mulheres Negras, 2019 